\title{
The case of Robert Antelme
}

\author{
Luba Jurgenson \\ University of Paris-Sorbonne (Paris-IV), France \\ e-mail: lubov.jurgenson@paris4.sorbonne.fr
}

\begin{abstract}
An analysis of the mnemonic mechanisms at work in the narrative of the concentration camp experience, based on the case of Robert Antelme. This survivor of the Buchenwald camp gave a first spoken version of what was to become his major work, l'Espèce humaine (The Human Species), to his friend Dionys Mascolo. Mascolo's testimony concerning the narrative that was told to him and his reception, some time later, of the written narrative (with the transition between the two versions marked by forgetting), question the notion of loss - in particular, the loss of a " 0 " text which is the text of death. This postulate allows us to explore the notion of the ineffable and to reveal its cultural implications; in other words, to approach the concept of survival as a narrative category.
\end{abstract}

There are two different approaches to survivor narratives. On the one hand, one may read them as literary texts constituting a sign system in relation to the referential world. On the other hand, one may also read them as testimony. In the latter case, survivor narratives amount to an object of anthropology of memory ${ }^{1}$ as their main aim is to preserve a trace of the events ${ }^{2}$. The narrative of Antelme, the genesis of which we have precise knowledge about, opens a vast field of study dealing with the mechanics of handing down experience ${ }^{3}$ as well as issues of its effacement ${ }^{4}$.

Cf. Ricoeur 2000.

Cf. Nora 1997.

Cf. Boursier 2002.

Cf. Agamben 1998. 


\section{Luba Jurgenson}

Robert Antelme, writer and resistance fighter, was arrested in 1944 and deported first to Buchenwald and then to Dachau (Lignes 21, 1994). On his liberation in 1945, he had the opportunity, of which others in the same situation were painfully deprived, of immediately describing his experience to the friend who had come to fetch him at the camp, Dionys Mascolo. These were, in a way, ideal conditions in which to produce testimony: the words spilled out freely, without any judicial, political or other sort of consideration, and they were received by a listener who was fully aware of the importance of his task and ready to offer his collaboration, insofar as it was possible, to create a lasting trace of the event by becoming a sort of co-witness. We have, in addition, the testimony given by Mascolo, the person who received this first spoken text, who was to be confronted with the problems of memory and forgetting experienced by the witnesses themselves. The literary document L'Espèce Humaine (The Human Species) would thus be coupled with a literary document concerning the genesis of this text, Autour d'un effort de mémoire (On an effort of memory) by Dionys Mascolo. This little book published in 1987 by Editions Maurice Nadeau allows us to investigate the blurred area which generally surrounds the genealogy of texts emerging from the experience of the concentration camps.

The spoken text elaborated by Robert Antelme immediately following his liberation prefigured, minus one episode, the written text of L'Espèce humaine. When, in 1947, Dionys Mascolo read the book, he recognised the spoken text and identified the one episode which had been added to the written version. This was the episode about sweeping the factory office (Antelme 1978: 56-57). Antelme, prisoner in the Buchenwald camp, weak and exhausted, was an unbearable sight for the young German employee who witnessed his desperate efforts to sweep the office. In the end, she grabbed the broom away from him and threw him out of the room.

Mascolo, however, does not tell us whether any part of the spoken text was omitted from the written version. For, although when he received the spoken narrative, he became its privileged and faithful guardian, no trace of the original remained when L'Espèce humaine, at the moment of publication, supplanted the spoken version. Forty years later, when he wrote his homage to Robert Antelme, his memory failed him: "[...] I am unable to retrieve the source of almost any of his words" (Mascolo 1987: 51). 
Nevertheless, in a letter written to Mascolo, Antelme seems to say that he used the distance that separated him from the experience to make his selection:

I would like to tell you other things on this subject that seem important to me, but I realise that I run a serious risk: D. I think that I no longer know what can be said and what cannot be said. In hell we say everything, in fact that must be how we know it is hell; as far as I am concerned, this is mainly how it was revealed to me. In our world, however, we tend to choose, and I think that I no longer know how to choose. (Mascolo 1987: 14)

Antelme and Mascolo made the return trip to Paris together, during which Antelme described, in jumbled order, all of the episodes which had taken place during his period of detention.

I know however that I registered these words, as they were being told, and in such a way that I could have written down the essential points myself if it happened that he died; we knew this, both of us, at the moment. This was the reason for our reciprocal avidity, for him to make me see, for me to discover the unimaginable, and our complicity, against the backdrop of his possible death, which did not permit us to rest. To be silent, to sleep, these were things we could not do without committing a crime. (Mascolo 1987: 51)

We could say that Mascolo lent his memory to Antelme in the physiological and medical sense of the word. At a certain moment, he substituted himself for Antelme, immersing himself in his experience to the point of being capable of bearing testimony in his place. But at another moment, he had already forgotten it all. The words were inside him, but he could no longer unreel them, as if he had swallowed the text.

It is precisely because I know everything that I cannot retrieve the source of almost any of his words. I must therefore, in what follows, place my confidence above all in the images I have kept of what surrounded us, the scenes or events that served as the external environment of these words, like their décor. (Mascolo 1987: 51)

The spoken text flowed from Antelme's memory into Mascolo's. Mascolo possessed the reality of the camps in place of his friend. Then, he evacuated it. We cannot impute this forgetting to the passing years. The forgetting of the source by the person who witnessed its 
outpouring dates from the era of the first reading of L'Espèce humaine. The episode that Mascolo remembered at that time was the one in which, during the death march from Buchenwald to Dachau, Antelme escaped from the column and was caught by some children. Why this episode rather than another? A wave of pity submerged the listener at this moment, writes Mascolo. For one instant, the listener ceased being the double of the witness, taking up his true place, that of an outside listener, through the filter of emotion.

As for the rest, I know only that, when I read it, I remembered that I had heard him tell it to me. (Mascolo 1987: 50)

In which moment was the spoken text evacuated? Visibly, at the moment of the discovery of the written text, it was already about to efface itself, for otherwise Mascolo would not have used the word "remember" which implies a re-memory, a rising to the surface of memory. The spoken text, first conscientiously registered, then entirely forgotten, rose to the surface once again at the moment of reading, both supplanted and resuscitated by the written word. Mascolo had appropriated the text so as to substitute himself for Antelme in the event of his death, for Antelme's survival was not yet certain. Memory functioned as a temporary graft; when the written text came into being, the body of the recipient was emptied. At the moment of transmission, Antelme was not yet a completely living person; he shared with those who had disappeared a knowledge immersed in oblivion. It was Antelme's potential death which gave the narrative its framework.

[...] For it's important for you to know, D., that during the first days when I was in my bed and when I talked to you, to you and to Marguerite especially, I was not a man of this earth. I insist on this fact which haunts me retrospectively. (Mascolo 1987: 92)

As long as Antelme remained a man not of this earth, Mascolo kept the text in his memory (Lignes 33: 210-211). If this text was no longer in his memory when Antelme showed that he had returned to life by putting his testimony into writing, it is because the spoken text no longer had a reason to exist. And, if Mascolo had forgotten a text that was of such importance to him, it is because it was not in his power to preserve it. The oral testimony emerged from the place of 
death. By lending his memory to Antelme, Mascolo was able to join him in that place, which he had subsequently to leave in order to continue to live.

This is thus a text whose emergence takes place in immediate contact with death and with which the survivor must cut his ties. Once the danger of death has been averted and the return to life given form in writing, the first text plunges into oblivion, making room for a lasting document which no longer risks being lost.

What gives us the sense of something irretrievable in the written documents concerning the concentration camps, something which cannot be put into words, would thus be due to the effacement of a text prior to testimony, the text of death, and its definitive supplanting by the written word. It is not because the experience of the camps cannot be put into words, but because it can be done so all too completely, whether in a language limited to a dozen terms or in an epic narrative, that the loss of this first document endures as a kind of primal wound which leaves its mark on all subsequent testimonies. What we call ineffable in the experience of the camps would thus be a way of naming a posteriori this disappearance of the text, associated with the return to life.

But what about the ineffable experience of which they (the words) are the echo? It is not the experience of the camps, which is only the cause, a necessary one to be sure. [...] The ineffable to which these words refer is itself contained in words which the present speaker sees himself as the witness of. [...] here, uniquely, the ineffable designates not what he, now a witness, heard as told to him (he was told), but indeed what he in his emotion, actively heard himself being told : and told to others - or told to us. (Mascolo 1987: 12)

We should keep in mind that this notion of the ineffable relies on what I would call the apophatic a priori, a major premise of European culture according to which a primary object exists which cannot be captured in thought or language. The narrative of the camps, transmitted within a given culture, inevitably assimilates its mechanisms while at the same time modifying them. The notion of the ineffable or inexpressible is one of the tools used by our culture to inhabit its shadowy or inaccessible areas, postulated as ante-predicative or metapredicative. 


\section{Luba Jurgenson}

What Mascolo recounts in his late testimony concerning the conditions in which L'Espéce Humaine was written is the loss of this first version of the text, an oral "rough draft" destined to disappear for the very reason that it was inscribed in the witness's body, in that particular state still linked to death (Sofsky 1995: 250).

We can thus postulate that in his role of substitute witness, Mascolo, whether he wished it to be so or not, reproduced the conditions of the testimony's emergence and that it was the text itself and not an individual memory which dictated these conditions. The body of the survivor, from which and in which the witness's testimony unfolds, has the dual status of object of investigation and exhibit. The paradox of reproducing the reality of the concentration camps consists precisely in this: at the very moment when the necessary words come into being, the body which authenticates this reality is no longer that of the wordless subject to which the testimony refers. The body of the Survivor at the moment of the writing has regained the vitality which the prisoner, lying between life and death, lacked. In the case of Robert Antelme, the written word came into being within two bodies, that of Antelme, who lived through the experience, and that of Mascolo, who did not; a body lying between life and death and whose outcome - life or death — was uncertain, and another body belonging to a healthy man who had never experienced this state, but who absorbed the text which reproduced it, like a cassette tape or a sheet of paper, thus becoming a medium, the materiality of Antelme's spoken text. Mascolo tells us nothing, for example, about the difference in tone between the spoken narrative and the written one, which henceforth belongs to the realm of literature, nor does he tell us anything about the writing in and of itself, nor about the way in which it transforms the testimony, he speaks only of the way the different episodes fit together, of their architecture; never does he discuss the text's corporality. He knew nothing of this, no doubt, when he received the testimony, for the simple reason that it was his own body which served as the guarantee of this corporality. Without him, the narrative would have remained in a phantom state, or more precisely: as a phantom pain. Or, to formulate it differently, Mascolo himself was the body of the text. When the text acquired a different materiality, that of the written word, he was then quite naturally divested of it. What could have been perceived of as an appropriation was in fact only a step in the elaboration of the testimony and was no 
more destined to "endure" than a single coat of paint amongst the successive coats of a painting elaborated with the glazing technique.

It is interesting to note that other Survivors of the camps were, in one way or another, threatened with the phenomenon of forgetting. Some would object to the term "threatened", considering that forgetting, in this case, was the result of a mechanism of self-defence set in motion precisely by a logic of survival, and that it could be considered as a salvation. Indeed certain recent psychoanalytical studies (Rosenblum 2000) tend to show that the obsessional conversion of memory into narration does not necessarily imply a logic of salvation but can on the contrary rekindle the trauma. To write about the experience of the camps would thus be tantamount, in a way, to not surviving. The suicide of a number of former prisoners (Primo Levi, Piotr Rawicz, Bruno Bettelheim, Tadeusz Borowski, Jean Améry, Sarah Koffman) seems to support this tendency or, at least, to alert us. Nevertheless, according to the witnesses themselves, forgetting would have added to the unbearable trauma of the camps, one more loss in the series of losses borne during imprisonment, thus becoming a reactivation of the experience of the camps. Here is what another French survivor of Buchenwald, David Rousset, says on the subject:

When I recovered from the typhoid fever, I experienced a very difficult period. Of course, I did remember that I had been imprisoned in the Nazi prison camps. For other people, forgetting everything would have been a veritable liberation, but not for me. I had the terrible feeling of having lost something essential, something extraordinarily precious.

Then came the period of my convalescence. [...] By dint of eating heavy cream, milk and fresh eggs, my health returned. I gained nearly a kilo every day. And, little by little, my memory came back. It was an impressive phenomenon. Each day, a new section of my memory returned so that in the end I had gotten it all back, except - and I didn't give a damn about that and still don't - part of the time I spent in hospital that never came back to me and that has been completely erased from my mind. (Copferman 1991: 77)

The section of his memories which had been definitively forgotten, which does not seem to have much value for David Rousset, most probably corresponds to the moment of his passage from death to life, precisely this same moment of passage which similarly occupies Mascolo's memories while subsequently being conspicuous by its absence, characterised by loss. Memory as it functions through words, 
and which includes the category of anteriority, cannot be achieved other than through the materiality of a body which has returned to life. Rousset's testimony is extremely precise concerning this point : memory depends on the weight of the flesh growing back onto the muscles. What, then, does the memory of a person who is at the limit between life and death consist in? Although Mascolo does not say much about Antelme's spoken narrative, for the simple reason that he cannot be at the same time both inside and outside the narrative (he cannot "visualise" it, because he is its receptacle), it is nonetheless significant that he mentions that Antelme told the story in jumbled order. In other words, the spoken narrative was not organised into a temporality implying a sequence of events going from a "before" to an "afterwards", but instead all the episodes were treated in a disorganised manner or as if they had all happened at the same time, in any case, in a non-linear time-space. If we keep in mind the fact that in the testimonies of most of the survivors, the temporality of the concentration camp was assimilated into a sort of present tense without past or future, without depth or evolution, we can thus conclude that the first spoken narrative was oriented towards a temporal model different from ours which mimed the temporality of the concentration camps. This "disorder" showed not so much the chaotic aspect of memory but rather a specific organisation of time that was perceived, from our vantage point, as disorder. The passage from the spoken to the written word, the "translation" of the experience into the language of the living implied a conversion into the reader's temporality, a conversion which took place precisely in the act of writing. The linearity which permitted the narrative to unfold, to be orchestrated into sequences, could not take place until the body's corporality had been retrieved and, with it, all the spatio-temporal co-ordinates in which it moved. Forgetting, the momentary loss of memory of the camps, probably corresponded to the passage from one temporality to the other, from the spatialised present to the linearity of successive instants (Halbwachs 1968).

As for Mascolo, he had never experienced the degradation of the body. If forgetting was only dependent on physical functions, there was no reason for him to mime the survivor's experience in this way. This enables us to affirm that the forgetting which affected Mascolo's testimony was, in a certain way, programmed by the text itself; it was a physical function of the text. The surviving body superimposed itself 
on the body of the text, with identical mechanisms taking place in each of them. What happened to Mascolo must also have happened to Antelme: he also forgot the first text. Indeed, the first text which contained the entire experience and adhered to it almost to the point of merging with it in an imperious desire to tell the story, together with other physical needs such as eating, drinking, and sleeping, could not be preserved in its principiality, for otherwise it would ensure the continuity of the very lack of differentiation which characterised the conscience of the concentration camp prisoners (Levi 1997).

This is what Antelme himself had to say about the first spoken narrative when L'Espèce Humaine was published:

Two years ago, during the first days following our return, we all, I believe, fell prey to a veritable delirium. We wanted to speak, to be heard at last. We were told that our physical appearance was already sufficiently eloquent. But we had just returned, we carried with us our memory, our living, breathing experience, and we had a frenetic desire to describe it as it had been. Yet, from the very first days, it seemed impossible for us to bridge the gap we discovered between the language available to us and this experience which, for most of us, we were still pursuing in our flesh. How could we resign ourselves to not trying to explain how we had gotten to this point? We were still there. And nevertheless it was impossible. No sooner had we begun to speak than we choked on the words. What we had to say began to seem unimaginable even to us. (Antelme 1947: 9)

We have seen elsewhere that the passage from one temporality to another implies a choice, and that even if Mascolo is unable to tell us anything about this choice, we can suppose that it was made in the act of writing. The first spoken text, in comparison with the written version, presents a kind of completeness, since we have been told that in hell everything could be said. From an act of speaking which includes everything we move to an act of writing filled with gaps, and at the same time, from the total solidarity of all the moments taken together, we move to a hierarchical organisation on the temporal axis. However, this "everything" that can be put into words is at the same time "nothing", since at the moment of leaving the concentration camp, nothing has yet been said and, precisely, everything has yet to be said. The totality of the word in the concentration camp is a mute word, total because it is mute and mute because it is total. It suffers from a globality that is cured by the language of a man who, once he has returned to "normal" life, can finally bear testimony. We might as 
well say that it is the metaphorical function of language that, in the concentration camps, is ill. The word is so close to the thing it designates that it is inextricable from it. ${ }^{5}$

The word "hell" used by Antelme is not a metaphor, it is "hell". The "everything can be said" of the camps implies that the gaps or incompleteness of language are not expressed: language thus loses one of its functions, which is to express its own insufficiency. The literature that emerged from the camps abounds in statements expressing the incapacity of words to describe the experience, statements that have justifiably given weight to the concept of the inexpressible. "This cannot be put into words": such is the leitmotiv running through innumerable testimonies about the camps. More generally, written and spoken language has the capacity to indicate the inadequacy of expression between what is experienced and how it is represented. However paradoxical it may seem, the ability to "say everything" supposes that the language of the camps, no matter how reduced it may be in the case of an exhausted prisoner, perfectly adheres to what it is trying to express and is thus wholly able to put the experience into words. (The more limited the language, the more significant is each sequence.)

When Antelme described his experience of the camps to Mascolo, he was no longer using this "total" language, because in the camps experience is not described, the events are not doubled by the spoken word but engraved in the body which alone is capable of reproducing them. We can nonetheless suppose that he attempted, in this first spoken version of the events, to represent that language. The pressure of the words makes us think that indeed something close to corporeal was taking place in the first moments following his liberation.

In his state of physical exhaustion, his only form of existence was through words. I didn't need to question him. He spoke about everything. Everything he had lived through for the past year, episode after episode, in no special order, each episode referring to another. To remain silent more than a few instants was impossible for him. He spoke in a continuous flow. Without hesitation, without commotion, as if under the pressure of a continuous source, possessed of the truly inexhaustible need to tell as much as he could before his possible death, and even death apparently had no importance for him other than this urgency to speak which its imminence imposed on him. I

5 Cf. Foucault 1969. 
think that we did not sleep more than four or five hours during the two days of the return trip. (Mascolo 1987: 49-50)

In conclusion, I would say that the fear of losing the testimony which forced Antelme to speak at the risk of his life, no doubt reveals a veritable loss in the passage from the experience to its representation. The concentration camp rendered after the event via its narrative conveys the idea (a kind of negative, infernal utopia) of an on-the-spot ontology, without recourse to the mediation of language. Something of this type of ontology can be seen in numerous accounts. However terrible the experience was, it nonetheless reveals a state of being which, on the verge of disappearing, can no longer be told and no longer needs to be told, attaining the self at the moment of the ultimate loss of self. As the space severed from the vast narrative of the world, the gaping yawn in the universal story, the camp itself cannot be described, in that the prisoner in his extreme state of existence no longer needs the personal narrative in order to communicate with his inner self. His inner self is directly accessible to him, and this accessibility is the very point at which he descends into death. It is probably this paradox that another Survivor, Primo Levi, tried to convey when he said that he had lived some of the most intense moments of his life in Auschwitz.

The Survivor moves away from this state of being, and his survival cannot be achieved except at this cost. By re-entering the narrative mechanisms that control our perception of the world, he returns to the living. The narrative leaves the body and organises itself on paper in ordered sequences of time rather than in blocks of speech which vie with the vital functions. What is at stake here, together with the biological phenomenon of the return to life, is sur-vival as a narrative category: regained life ceases to be the sole objective and is doubled by a narrative which superimposes itself upon it by pushing the pure sensation of existence into the zone of presupposition, not directly accessible by perception. 


\section{References}

Agamben, Giorgio 1998. Quel che resta di Auschwitz. Torino: Bollati Boringhieri. Antelme, Robert 1978 [1947]. L'Espèce humaine. Paris: Gallimard (collection "TEL"). [First publication: 1947. Paris: Editions de la Cité Universelle. Republished by Gallimard in 1957.]

Bloch, Marc 1974. Apologie pour l'histoire. Paris: Armand Colin.

Boursier, Jean-Yves 2002. La mémoire comme trace des possibles. Traces, SocioAnthropologie 12: 5-22.

Copferman, Emile 1991. David Rousset, une vie dans le siècle. Fragments d'autobiographie. Paris: Plon.

Coquio, Catherine 2000. Parler des camps, penser les génocides. Paris: Albin Michel.

Crowley, Martin 2004. Robert Antelme, l'humanitè irréductible. Paris: Léo Scheer, Lignes.

Dobbels, Daniel 1996. Textes inédits. Sur "L'Espèce humaine”. Essais et témoignages. Paris: Gallimard.

Dobbels, Daniel; Moncond'huy, Dominique 2000. Les Camps et la littérature: une littérature du XXe siècle. Poitiers: UFR Langues et littératures.

Duras, Marguerite 1993. La Douleur. Paris: Gallimard.

Foucault, Michel 1969. L'archéologie du savoir. Paris, Gallimard (Bibliothèque des sciences humaines).

Halbwachs, Maurice 1968. La Mémoire collective. Paris: PUF.

Kogon, Eugen 1993. L'Etat SS. Paris: Le Seuil (Points Histoire).

Levi, Primo 1997. Conversazioni e interviste. Torino: Einaudi.

Lignes 21 = Collectif 1994. Présence de l'Espèce humaine. (Lignes 21.) Paris: Hazan.

Lignes 33 = Collectif 1998. Avec Dionys Mascolo. (Lignes 33: special issue.) Paris: Hazan.

Mascolo, Dionys 1987. Autour d'un effort de mémoire. Paris: Editions Maurice Nadeau.

Nora, Pierre 1997 [1984-1992]. Les Lieux de mémoire. Paris: Gallimard.

Ricoeur, Paul 1985. Temps et récit. Paris: Seuil.

- 2000. La mémoire, l'histoire, l'oubli. Paris: le Seuil.

Rosenblum, Rachel 2000. Mourir de dire. Revue française de psychanalyse 64(1): 113-137.

Sofsky, Wolfgang 1995. L’Organisation de la terreur. Paris: Calmann-Lévy. 


\section{Случай Робера Антельма}

Настоящая статья анализирует на примере Робера Антельма мнемонические механизмы, которые работают при рассказе об опыте жизни в концлагере. Робер Антельм выжил в Бухенвальде и первую версию о своих переживаниях (позже на этой основе была издана его главная книга «Род человеческий») он рассказал своему другу Дионису Маскало. Высказывания Маскало по поводу этого рассказа и своего отношения к описанному потом в книге (разницу в двух версиях можно характеризовать ключевым понятием забвение) ставят в фокус понятие потери - точнее, потери так называемого «нулевого текста», т.е. текста смерти. Подобное утверждение позволяет нам изучить понятие невыражаемого и выявить культурные импликации невыражаемости. Другими словами, таким образом становится возможным описать понятие выживания в качестве нарративной стратегии.

\section{Robert Antelme'i juhtum}

Artikkel analüüsib Robert Antelme'i näitel mnemoonilisi mehhanisme, mis toimivad koonduslaagri kogemuse jutustamisel. Robert Antelme pääses eluga Buchenwaldi laagrist ning esimese versiooni tema läbielamistest, millest hiljem sai Antelme'i peateos l'Espèce humaine (Inimsugu), esitas ta suulise jutustusena oma sõbrale Dionys Mascalole. Mascolo ütlused selle loo kohta, mida talle jutustati, ning see, kuidas ta hiljem kirjutatud loo vastu võttis (nende kahe versiooni vahel toimunud muutuse võtmesõnaks on unustamine), seavad fookusesse kaotuse mõiste - täpsemalt nn "nullteksti”, st surmateksti kaotuse. Taoline väide annab meile võimaluse uurida väljendamatuse mõistet ning tuua esile väljendamatuse kultuurilised implikatsioonid, ehk teisisõnu saab selle läbi võimalikuks käsitleda ellujäämise mõistet kui narratiivset strateegiat. 
